\title{
Erratum to: Tumor markers in mature cystic teratomas of the ovary
}

\author{
Emin Ustunyurt - Tayfun Gungor • Cantekin Iskender • \\ Basak Ozlem Ustunyurt • Umit Bilge • \\ Leyla Mollamahmutoglu
}

Published online: 5 October 2014

(c) Springer-Verlag Berlin Heidelberg 2014

Erratum to: Arch Gynecol Obstet (2009) 279:145-147

DOI 10.1007/s00404-008-0688-2

Unfortunately, the given and family names of the complete author group was interchanged in the official publication of the article. The correct author group is given below.

Emin Ustunyurt, Tayfun Gungor, Cantekin Iskender, Basak Ozlem Ustunyurt, Umit Bilge, Leyla Mollamahmutoglu

The online version of the original article can be found under doi:10.1007/s00404-008-0688-2.

E. Ustunyurt - T. Gungor - C. Iskender ·

B. O. Ustunyurt · U. Bilge · L. Mollamahmutoglu

The Department of Obstetrics and Gynecology,

Zekai Tahir Burak Women's Health Education Hospital,

Ankara, Turkey

E. Ustunyurt ( $\square)$

Turan Gunes Bulvar1, Korman Sitesi 51/B-11,

06460 Ankara, Turkey

e-mail: dreminustunyurt@yahoo.com.tr 